\title{
Features of the composition of metapelites from the basement of the Arctic part of the West Siberian megabasin (Verkhnerechenskaya exploration area, Yamal Peninsula)
}

\author{
Vladimir Sergeevich PONOMAREV* \\ Kirill Svyatoslavich IVANOV** \\ Yuriy Viktorovich EROKHIN*** \\ Nadezhda Nikolaevna FARRAKHOVA****
}

The Zavaritsky Institute of Geology and Geochemistry of the Ural Branch of RAS, Ekaterinburg, Russia

\section{Abstract}

Relevance of the work. Comprehensive studies of the geology of the Arctic part of Western Siberia are very important for the search for oil and gas in this vast but understudied territory. At present, unfortunately, we know little about the geological structure of the Arctic in the region of Western Siberia, where the sedimentary cover is mainly investigated (the thickness of which is about 3-4 km) and only a few wells are drilled to the foundation. Therefore, a comprehensive study of core samples from this little-studied territory seems extremely relevant.

The purpose of the work is a detailed description of the mineralogy and petro-geochemical features of garnetquartz-chlorite-muscovite schists from the well Verkhnerechenskaya no. 2 from the foundation Arctic part of the West Siberian megasbasin.

Scope of application of work. This work can be useful in constructing geological maps of the pre-Jurassic foundation of the Yamal Peninsula.

Results of work and conclusions. Mineralogy has been studied in detail and the trace element composition of garnetquartz-chlorite-muscovite schists is obtained. The mineral composition of the rocks is as follows: almandine, muscovite, quartz, chamosite, calcite, albite, rutile, titanite, fluorapatite, zircon, xenotime-(Y) and pyrite. The progressive zonality in the almandine is determined, which is confirmed by the calculated data of metapelite formation temperature, progressive metamorphism. Distribution of rare, scattered and REE in the studied rocks is characteristic of metamorphic schists from the foundation of the Urals part of the West Siberian megasbasin, which compel the framing of monzodiorite-granite massifs of Shaimsko-Kuznetsov meganticlinorium of Western Siberia. Probably, the metapelites studied are the result of warming up the thickness of sedimentary rocks with granite intrusion located in the vicinity of Verkhnerechenskaya area. Later, the rocks underwent propylitization with the formation of secondary carbonate and pyrite.

Keywords: mineralogy, metamorphic schists, metapelites, basement, Yamal Peninsula, Western Siberia.

Introduction

Comprehensive studies of the geology of the Arctic part of Western Siberia are very important for the search for oil and gas in this vast but understudied territory. In addition to Jurassic and Cretaceous rocks of the sedimentary cover of the West Siberian megabasin, perspective rocks for hydrocarbons are also granitoids of the foundation and their metamorphic framing [1-3].

Within the territory of the Yamal Peninsula, the foundation rock complexes were opened with wells within Bovanenkovskaya, Novoportovskaya, Verkhnerechenskaya and Syunai-Salinskaya exploration areas. Verkhnerechenskaya area is located in the southern part of the Yamal Peninsula, near the Novoportovsky oil and gas field. Earlier, in the territory of Verkhnerechenskaya area (well no. 1) we investigated granites opened by the well in the depth interval 1748-2034 m. Well Verkhnerechenskaya no. 3 at a depth of 1730-1827 $\mathrm{m}$ also exposed granites but sheeted ones [4]. Approximately $15 \mathrm{~km}$ east of well no. 3, Verkhnerechenskaya well no. 2 was drilled, in which metamorphic rocks, garnet-quartz-chlorite-mica composition were exposed in depth range 2480-2600 m (fig. 1). To the north of the Verkhnerechenskaya area, in the Zapadno-Yarotinskaya area in the pre-Jurassic basement, metamorphic schists were drilled, which we consider as the northern framing of the Verkhnerechenskaya granite pluton [5], the age of which is determined by accessory zircons and monazite, and corresponds to the Late Permian (254-256 Ma) [4, 6] The schists have 


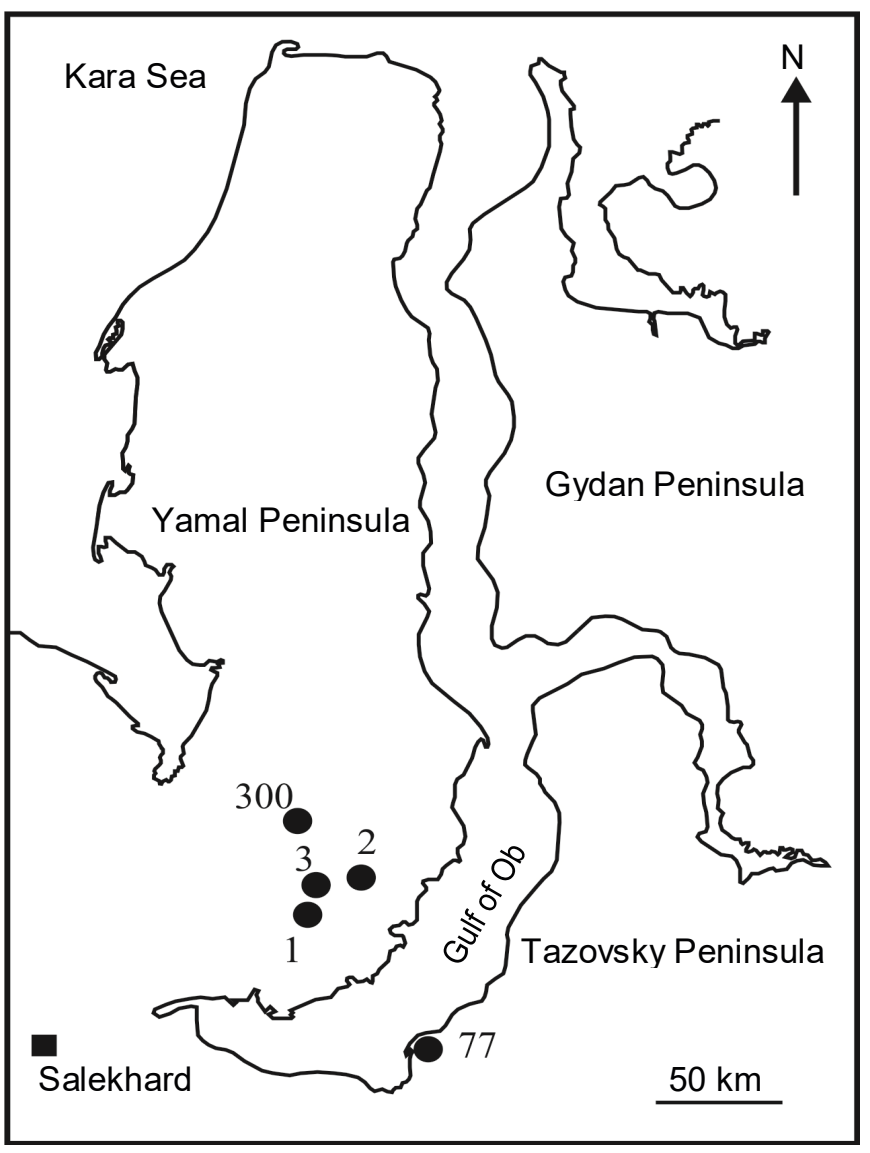

Figure 1. Schematic map of the location of the wells that opened the foundation. Well numbers: 1-3 - Verkhnerechenskaya, 300 - Zapadno-Yarotinskaya, 77 - Lenzitskaya

Рисунок 1. Схематическая карта расположения скважин, вскрывших фундамент. Номера скважин: 1-3 - Верхнереченская, 300 - Западно-Яротинская, 77 - Лензитская

a quartz-plagioclase-mica-chlorite composition and were formed under conditions of greenschist metamorphism over the sedimentary substrate, and later underwent secondary alterations in the process of superimposed propylitization. Until recently, nothing was known about the age of the metamorphic schists from the basement of the Yamal Peninsula, and it was initially believed that they belong to the Precambrian formations [7]. Recently V. S. Bochkarev and his colleagues attempted to confirm this statement; they were engaged in $\mathrm{U}-\mathrm{Pb}$ dating of accessory zircons. So, in the schists of the well Verkhnerechenskaya no. 2, they have determined the Mesoproterozoic age of $1168 \pm 13 \mathrm{Ma}$; in the rocks of the Zapadno-Yarotinskaya area in the well no. $302-552 \pm 13 \mathrm{Ma}$; in the well no. $303-519$ and $978 \pm 10 \mathrm{Ma}$ [8]. It would seem that the attempt was successful and it really turns out that the schists are of ancient age, within the Cambrian-Precambrian. But the authors did not take into account the fact that zircon is a very stable mineral, it is easily redeposited and, at the same time, does not restart the isotope system with relatively weak metamorphism. That is, the dating obtained is only the age of detrital zircon, which, moreover, in many studies turned out to be rounded in shape. At the same time, we determined the age of metamorphism $\left({ }^{40} \mathrm{Ar} /{ }^{39} \mathrm{Ar}\right.$-method, $\left.\approx 271 \mathrm{Ma}\right)$ of similar metamorphic schists from the basement of the Tazovsky Peninsula in Western Siberia (Lenzitskaya area, well no. 77). Metamorphism of sediments took place under the influence of a powerful tectonic-magmatic event - the beginning of the formation of the Permian-Triassic rifts and outflow of basalts, and the obtained dating $\approx 252 \mathrm{Ma}$ coincides in time with the period of the most intense formation of submeridional striking rifts in the basement of the West Siberian platform [9]. This work provides a detailed description of the mineralogy and features of the microelement composition of garnet-quartz-chlorite-muscovite schists from the Verkhnerechenskaya well no. 2 from the basement of the Arctic part of the West Siberian megabasin.

Object of research

We have examined some core samples of garnet-quartz-chlorite-muscovite schists from a depth of $2562.5 \mathrm{~m}$. The structure of the rocks is from granoblastic to granolepidoblastic, the texture is layered. The mineral composition of the rock is represented by muscovite, quartz, chamosite, calcite, albite, almandine, rutile, fluorapatite, zircon, xenotime-(Y), and pyrite.

Research methods

Analytical studies presented in this work were carried out in the laboratory of physical and chemical research methods of the Institute of Geology and Geochemistry, Ural Branch of the Russian Academy of Sciences, Ekaterinburg. The chemical composition of metamorphic schists was determined using the Shimadzu XRF 1800 X-ray fluorescence spectrometer equipped with an X-ray tube (4 kW, Rh-anode), TAP, PET, Ge, LiF analyzer crystals (200), as well as a vacuum stabilizer, flow proportional and scintillation counters (analyst is N. P. Gorbunova). Losses during ignition and iron oxide were determined by the wet chemistry method (analyst is G. S. Neupokoeva). The content of rare scattered and rare-earth elements was determined using the ELAN-9000 inductively coupled plasma mass spectrometer (PerkinElmer Instruments); analysts are N. V. Cherednichenko and D. V. Kiseleva. The chemical composition of minerals was analyzed in polished thin sections using the CAMECA SX 100 electron probe microanalyzer with five wave spectrometers (analyst is I. A. Gottman). The study of accessory and sulfide mineralization was carried out using the Jeol JSM-6390LV scanning electron microscope with an INCA Energy 450 X-Max 80 energy dispersive attachment from Oxford Instruments (analyst is N. N. Farrakhova). Photographs of minerals in the backscattered electron mode were obtained using the same device.

Results of the study

The rocks are fine-grained, greenish-gray in color, microscopically there is an alternation of layers of finegrained quartz aggregate with inclusions of chlorite, grains of carbonate and mica with layers of chlorite-mica fine-grained aggregate. Micro-folding is observed in the rock (fig. 2), which is a consequence of the intense deformation of the rocks.

In garnet-quartz-chlorite-muscovite schists, quartz is represented by polygonal and rounded grains with numerous inclusions of both rock-forming and accessory 

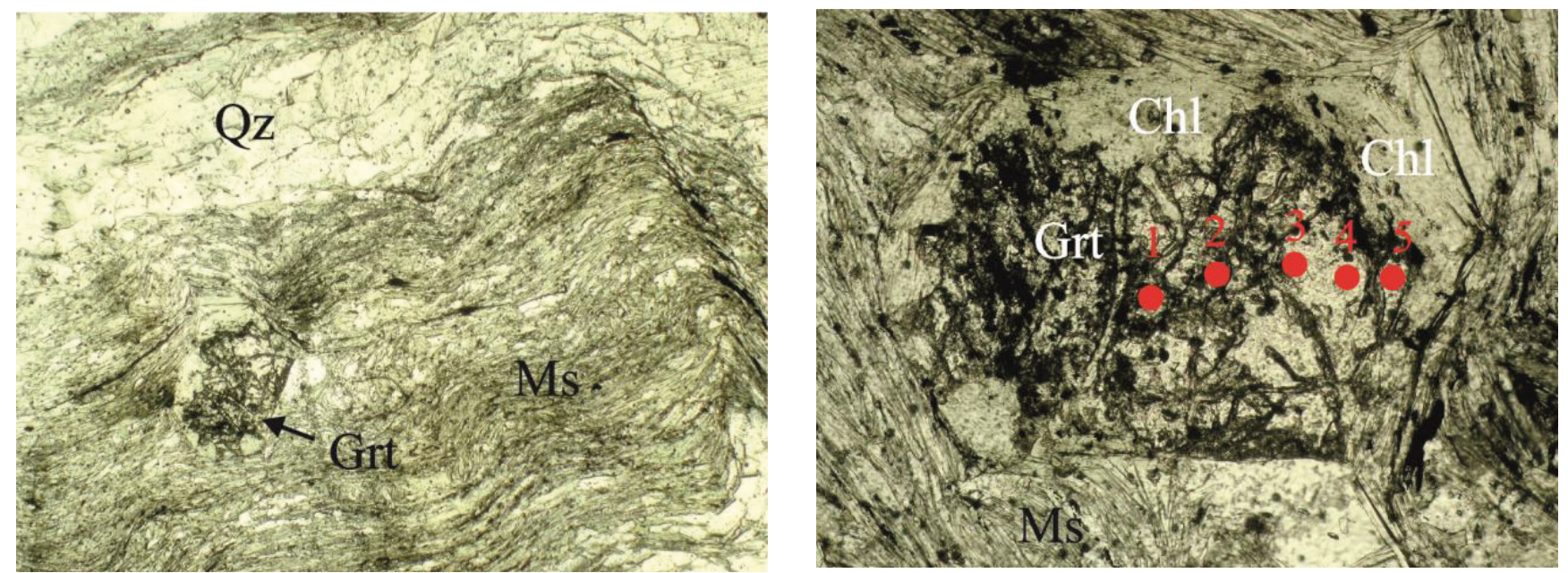

Figure 2. Garnet quartz-chlorite-muscovite schist. Well Verkhnerechenskaya no. 2, depth is $\mathbf{2 5 6 2 . 5} \mathrm{m}$. Transmitted light, without analyzer, the size of field of view is $5 \mathrm{~mm}$. Here and in fig. 3,4 and 5. Qz - quartz, Grt - garnet, Ms - muscovite

Рисунок 2. Гранат-кварц-хлорит-мусковитовый сланец. Скв. Верхнереченская № 2, гл. 2562,5 м. Проходящий свет, без анализатора, размер поля зрения 5 мм. Здесь и на рис. 3, 4 и 5: Qz - кварц, Grt - гранат, Ms - мусковит

Figure 3. Grain of garnet. Without an analyzer, the size of the field of view is $1.5 \mathrm{~mm}$ (numbers indicate the numbers of microprobe analyzes from table 2). Here and in Figure 4: $\mathrm{Chl}-$ chlorite

Рисунок 3. Зерно граната. Без анализатора, размер поля зрения 1,5 мм (цифрами даны номера микрозондовых анализов из табл. 2). Здесь и на рис. 4: $\mathrm{Chl}$ - хлорит

minerals. Often in the rock, you can observe a block and undulating extinction in polarized light in quartz grains. Grains size is up to $0.1 \mathrm{~mm}$. Quartz contains small inclusions of chlorite, muscovite, rutile, apatite, zircon, and xenotime. Mica forms fine-grained banded, deformed, folded aggregates together with chlorite plates. The size is up to $0.2 \mathrm{~mm}$. Individuals of albite, zircon, apatite, and rutile are found among the chlorite-mica layered aggregate. According to the classification [10], mica correspond to muscovite (table. 1, an. 1-2). In the mineral there is an admixture of $\mathrm{FeO}$ up to 2.43 mas.\%, $\mathrm{MgO}$ to 1.58 mas. $\%, \mathrm{Na}_{2} \mathrm{O}$ to 0.85 mas. $\%$ and $\mathrm{TiO}_{2}$ to 0.39 w.\%. Chlorite in the rock forms thin-scaled grain aggregates among muscovite individual; it is sometimes noted as separate individuals in the interstices of quartz grains and in the form of inclusions. The size of chlorite individual does not exceed $0.4 \mathrm{~mm}$. By chemical composition, it corresponds to magnesial chamosite. $\mathrm{MgO}$ content in chlorite up to 13.35 w.\%, $\mathrm{MnO}$ up to $0.30 \mathrm{w} . \%$ (table 1 , an. 3-6).

Garnet in the rock forms grains up to $1.1 \mathrm{~mm}$ in size. The shape of the grains is close to isometric. In thin sections, garnet has hexagonal sections of rhombododecahedron crystals. In the grains of garnet, its replacement with chlorite is observed (fig. 3) preserving its original outlines. Cracks in the mineral are also made by chlorite. Isotropic. In terms of chemical composition, garnet belongs to almandine with a high content of grossular (up to $30.3 \%$ ) and spessartine (up to $20.5 \%$ ) minals (table 1, an. 7-12; table 2). In the almandine crystal, 5 microprobe analyzes were performed from the central part to the periphery (fig. 3). In the mineral, there is a gradual increase (table 2, an. 1-5) of the almandine, pyrope, and andradite minal and a decrease in the grossular and spessartine minal from the center of the crystal (Alm ${ }_{472} \mathrm{Grs}_{295} \mathrm{Sps}_{205} \operatorname{Prp}_{22} \mathrm{Adr}_{0.6}$ ) to the edge ( $\mathrm{Alm}_{56.2} \mathrm{Grs}_{29.9} \mathrm{Sps}_{9.8} \operatorname{Prp}_{3.0} \mathrm{Adr}_{1.1}$ ). An increase in the $\mathrm{MgO}$ content from the center to the edge in garnet and a decrease in the $\mathrm{MnO}$ content correspond to progressive metamorphic zoning [11].

Another microprobe analysis of a garnet was made in a small isometric garnet fragment with an irregular shape. Judging by the chemical composition, it can be assumed that this analysis was made in a fragment, most likely from the peripheral part of the crystal. Its minal composition is $\mathrm{Alm}_{61.5} \mathrm{Grs}_{25.4} \mathrm{Sps}_{8.0} \operatorname{Prp}_{34.4} \mathrm{Adr}_{0.7}$ (table 2, an. 6).

In general, garnet is quite rare in the metamorphic rocks of the basement of Western Siberia. Earlier, almandine with progressive zoning was described by us from the quartz-sericite and quartz-biotite schists of the East-Urayskaya area (well no. 201) in the Shaimsky region of Western Siberia [12].

Using a garnet-muscovite geothermometer [13], the temperature of formation of the studied schists was calculated. In the center of individuals, the calculated temperature was $380^{\circ} \mathrm{C}$; in the edge part of the garnet $435^{\circ} \mathrm{C}$. Thus, an increase in temperature from the center to the edges of grains in almandine is observed, which probably indicates progressive metamorphism. The substitution of chlorite for the marginal parts of the garnet indicates that the progressive stage subsequently gave way to regressive metamorphism. The chlorite formation temperature was calculated using a chlorite thermometer [14] and is estimated in the range of $280-290^{\circ} \mathrm{C}$. In general, the temperatures obtained correspond to the level of the greenschist facies of metamorphism (during garnet formation, the tops of the greenschist facies, and during the regressive stage, the lower strata of greenschist facies). 
Table 1. Chemical composition of minerals from the Verkhnerechensky schist, wt.\%

Таблица 1. Химический состав минералов из верхнереченского сланца, мас.\%

\begin{tabular}{|c|c|c|c|c|c|c|c|c|c|c|c|c|c|}
\hline $\begin{array}{l}\text { Analysis } \\
\text { number }\end{array}$ & $\mathrm{SiO}_{2}$ & $\mathrm{TiO}_{2}$ & $\mathrm{Al}_{2} \mathrm{O}_{3}$ & $\mathrm{Cr}_{2} \mathrm{O}_{3}$ & $\mathrm{P}_{2} \mathrm{O}_{5}$ & $\mathrm{FeO}$ & $\mathrm{MnO}$ & $\mathrm{MgO}$ & $\mathrm{CaO}$ & $\mathrm{Na}_{2} \mathrm{O}$ & $\mathrm{K}_{2} \mathrm{O}$ & $F$ & Total \\
\hline \multicolumn{14}{|c|}{ Muscovite } \\
\hline 1 & 49.19 & 0.29 & 31.93 & - & - & 2.43 & 0.10 & 1.58 & - & 0.84 & 9.59 & 0.19 & 96.14 \\
\hline 2 & 49.34 & 0.39 & 31.87 & - & - & 2.09 & 0.02 & 1.47 & - & 0.85 & 9.82 & 0.16 & 96.01 \\
\hline \multicolumn{14}{|c|}{ Chlorite } \\
\hline 3 & 24.95 & 0.08 & 21.16 & 0.01 & - & 25.93 & 0.19 & 13.13 & 0.01 & - & 0.01 & 0.20 & 85.67 \\
\hline 4 & 26.01 & 0.04 & 22.06 & 0.13 & - & 25.31 & 0.16 & 13.04 & 0.04 & 0.03 & 0.02 & 0.09 & 86.93 \\
\hline 5 & 24.53 & 0.02 & 21.98 & - & - & 26.07 & 0.18 & 13.35 & - & - & 0.01 & 0.12 & 86.26 \\
\hline 6 & 24.71 & 0.06 & 21.43 & 0.02 & - & 26.99 & 0.30 & 12.61 & 0.04 & - & - & 0.16 & 86.32 \\
\hline \multicolumn{14}{|c|}{ Almandine } \\
\hline 7 & 37.40 & 0.15 & 20.63 & 0.05 & - & 21.67 & 9.07 & 0.56 & 10.50 & 0.02 & - & - & 100.05 \\
\hline 8 & 37.26 & 0.15 & 20.77 & 0.05 & - & 21.50 & 8.85 & 0.57 & 10.82 & 0.02 & - & - & 99.99 \\
\hline 9 & 37.23 & 0.20 & 20.87 & 0.07 & - & 22.85 & 8.27 & 0.58 & 10.19 & - & - & - & 100.26 \\
\hline 10 & 37.09 & 0.04 & 20.87 & 0.01 & - & 24.44 & 6.50 & 0.67 & 10.56 & 0.01 & - & - & 100.19 \\
\hline 11 & 36.96 & 0.06 & 20.64 & 0.06 & - & 25.91 & 4.26 & 0.75 & 10.72 & - & - & - & 99.36 \\
\hline 12 & 37.21 & 0.04 & 21.01 & 0.05 & - & 28.09 & 3.52 & 1.09 & 9.03 & 0.05 & - & - & 100.09 \\
\hline \multicolumn{14}{|c|}{ Albite } \\
\hline 13 & 67.74 & - & 19.15 & 0.04 & - & 0.17 & - & 0.01 & 0.15 & 11.91 & 0.16 & - & 99.33 \\
\hline 14 & 68.22 & - & 19.37 & - & - & 0.12 & - & - & 0.14 & 12.04 & 0.07 & - & 99.96 \\
\hline 15 & 68.24 & - & 19.66 & 0.02 & - & 0.13 & - & - & 0.09 & 11.93 & - & - & 100.07 \\
\hline 16 & 68.96 & - & 19.01 & 0.07 & - & 0.08 & - & 0.01 & 0.02 & 11.96 & - & - & 100.11 \\
\hline \multicolumn{14}{|c|}{ Rutile } \\
\hline 17 & 0.15 & 99.85 & 0.15 & 0.06 & - & 0.25 & - & 0.01 & - & - & 0.01 & - & 100.48 \\
\hline \multicolumn{14}{|c|}{ Fluorapatite } \\
\hline 18 & - & - & - & - & 42.78 & 0.10 & 0.05 & - & 57.10 & - & - & 4.04 & 104.07 \\
\hline 19 & - & - & - & - & 42.59 & 0.16 & 0.08 & - & 56.84 & - & - & 3.67 & 103.34 \\
\hline \multicolumn{14}{|c|}{ Calcite } \\
\hline 20 & - & - & - & - & - & 1.45 & 3.71 & 0.46 & 54.01 & 0.02 & 0.13 & - & 59.78 \\
\hline 21 & - & - & - & - & - & 0.86 & 1.02 & 0.12 & 54.50 & 0.17 & - & - & 56.67 \\
\hline 22 & - & - & - & - & - & 1.30 & 0.70 & 0.34 & 57.06 & 0.04 & - & - & 59.44 \\
\hline
\end{tabular}

Table 2. Minal composition of garnet, \%

Таблица 2. Минальный состав граната, \%

\begin{tabular}{cccccc}
\hline \multirow{2}{*}{ Analysis number } & \multicolumn{5}{c}{ Minals } \\
\cline { 2 - 6 } & Almandine & Grossular & Spessartine & Pyrope & Andradite \\
\hline 1 & 47.2 & 29.5 & 20.5 & 2.2 & 0.6 \\
2 & 46.5 & 30.3 & 20.1 & 2.3 & 0.8 \\
3 & 49.8 & 28.5 & 18.8 & 2.3 & 0.6 \\
4 & 51.9 & 29.2 & 14.8 & 2.7 & 1.4 \\
5 & 56.2 & 29.9 & 9.8 & 3.0 & 1.1 \\
6 & 61.5 & 25.4 & 8.0 & 4.4 & 0.7 \\
\hline
\end{tabular}

Plagioclase in a schist is rare enough. Separate nontwinned and tabular plagioclase grains up to $0.15 \mathrm{~mm}$ in size are noted among the chlorite-mica aggregate. In terms of chemical composition, the mineral corresponds to pure albite $\left(\mathrm{An}_{0.1-0.7}\right)($ table 1 , an. 13-16).
Rutile in the rock occurs in both chlorite-muscovite and quartz aggregates in the form of elongated individuals up to $0.4 \mathrm{~mm}$ in size, oriented along the schistosity of the rock. The mineral forms translucent grains of light brown color. According to microprobe analysis, rutile 


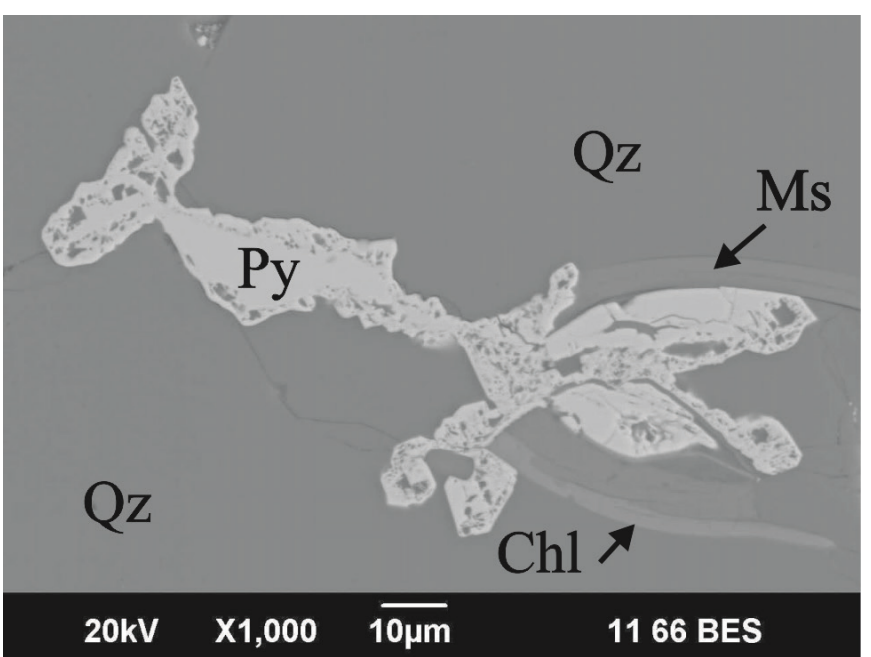

Figure 4. Pyrite grain from garnet-quartz-chlorite-muskovite schist. Well Verkhnerechenskaya no 2, depth is $2562.5 \mathrm{~m}$. BSE-image: Py - pyrite

Рисунок 4. Зерно пирита из гранат-кварц-хлорит-мусковитового сланца. Скв. Верхнереченская № 2, гл. 2562,5 м. BSE-изображение: Ру - пирит

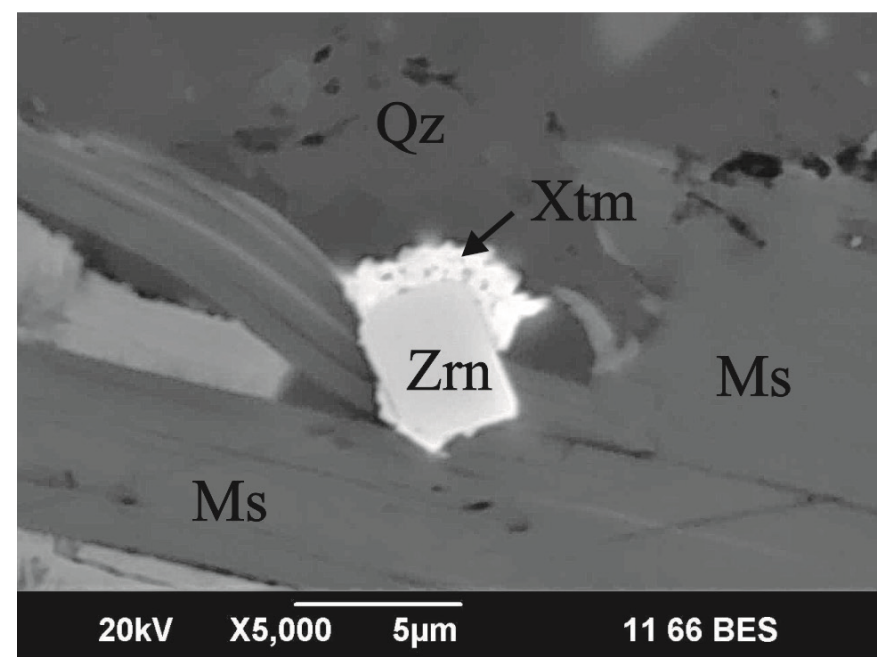

Figure 5. Zircon grain with xenotime-(Y) from garnet-quartz-chlorite-muskovite schist. Well Verkhnerechenskaya no 2, depth is $2562.5 \mathrm{~m}$. BSE-image: $\mathrm{Zrn}$ - zircon, $\mathrm{Xtm}$ - xenotime

Рисунок 5.Зерноцирконас ксенотимом-(Y) из гранат-кварц-хлорит-мусковитового сланца. Скв. Верхнереченская № 2, гл. 2562,5 м. BSE-изображение: Zrn - циркон, Xtm - ксенотим practically does not contain impurities (table 1 , analysis 17 ). Titanite in a schist composes fine elongated grains up to $20 \mu \mathrm{m}$ in size in a quartz aggregate. In the chemical composition of the mineral there are impurities $\mathrm{Al}_{2} \mathrm{O}_{3}$ up to 2.06 wt.\% and $\mathrm{FeO}$ up to $0.30 \mathrm{wt} . \%$.

In the interstices of grains of quartz, carbonate and in the form of inclusions in them, there are short-prismatic apatite individuals up to $30 \mu \mathrm{m}$ in size. According to the chemical composition, the mineral corresponds to fluorapatite (table. 1, an. 18, 19).

Carbonate in schists is confined to a quartz aggregate and often fissures in the rock. It forms elongated and isometric grains up to $1 \mathrm{~mm}$ in size, in which polysynthetic twinning is often observed. The composition of the carbonate corresponds to calcite. The following impurities in calcite are found: $\mathrm{MnO}$ up to $3.71 \mathrm{wt} . \%, \mathrm{FeO}$ up to 1.45 wt.\% and $\mathrm{MgO}$ up to 0.46 wt.\%.

Zircon is evenly distributed throughout the rock. Short-prismatic crystals of the mineral are observed both in the intergranular space of rock-forming minerals and in the form of inclusions in them. In the composition of zircon there is an admixture of $\mathrm{HfO}_{2}$ up to $1.74 \mathrm{wt} . \%$. Xenotime-(Y) was found in small numbers, in the form of single individuals of isometric shape, up to $10 \mu \mathrm{m}$ in size, and in the form of "outgrowths" on zircon grains (fig. 5). The mineral contains a significant amount of impurities of heavy rare earth elements, as well as thorium up to $1.78 \mathrm{wt} . \%$ and uranium up to $1.75 \mathrm{wt} . \%$.

Sulfide mineralization of the studied rocks is represented by pyrite. The mineral forms irregular grains up to $150 \mu \mathrm{m}$ in size and elongated grain aggregates up to $1 \mathrm{~mm}$ located along the schistosity of the rock. The growth of pyrite of a cellular appearance of the second generation is observed on sulfide grains (fig. 4). The chemical composition of the mineral contains an admixture of $\mathrm{Pb}$ up to $0.3 \mathrm{wt} . \%$ (table 3). We also noted a similar lead admixture in pyrites from schists in the basement of the Lenzitskaya area in the southwestern part of the Tazovsky Peninsula [15]. Pyrite mineralization in garnet-quartz-chlorite-mica schists, most likely, was formed during the superimposed propylitization.

Table 3. Chemical composition of pyrite from metamorphic schists, wt.\%

Таблица 3. Химический состав пирита из метаморфических сланцев, мас.\%

\begin{tabular}{|c|c|c|c|c|}
\hline \multirow{2}{*}{ Analysis number } & \multicolumn{3}{|c|}{ Elements } & \multirow{2}{*}{ Total } \\
\hline & $\mathrm{Fe}$ & $\mathrm{Pb}$ & $S$ & \\
\hline 1 & 46.79 & 0.10 & 53.04 & 99.93 \\
\hline 2 & 46.88 & 0.16 & 54.02 & 101.06 \\
\hline 3 & 46.93 & 0.16 & 53.63 & 100.72 \\
\hline 4 & 47.01 & 0.27 & 53.49 & 100.77 \\
\hline 5 & 46.33 & 0.34 & 53.51 & 100.18 \\
\hline
\end{tabular}


Table 4. Chemical (wt.\%) and trace element composition (ppm) of Verkhnerechensky schist

Таблица 4. Химический (мас.\%) и микроэлементный состав (г/т) верхнереченского сланца

\begin{tabular}{|c|c|c|c|c|c|c|c|c|c|}
\hline Oxides & Sample & Elements & Sample & Elements & Sample & Elements & Sample & Elements & Sample \\
\hline $\mathrm{P}_{2} \mathrm{O}_{5}$ & 0.15 & V & 120.00 & Y & 21.00 & $\mathrm{Pr}$ & 4.00 & $\mathrm{Ta}$ & 0.35 \\
\hline $\mathrm{SiO}_{2}$ & 57.36 & $\mathrm{Li}$ & 20.00 & As & 9.70 & Cs & 1.60 & $\mathrm{Tm}$ & 0.32 \\
\hline $\mathrm{TiO}_{2}$ & 0.79 & $\mathrm{Be}$ & 1.10 & $\mathrm{Se}$ & 0.47 & $\mathrm{Ba}$ & 410.00 & $\mathrm{Yb}$ & 2.10 \\
\hline $\mathrm{Al}_{2} \mathrm{O}_{3}$ & 16.90 & Sc & 21.00 & $\mathrm{Rb}$ & 110.00 & La & 15.00 & Lu & 0.30 \\
\hline $\mathrm{Fe}_{2} \mathrm{O}_{3}$ & 2.78 & $\mathrm{Ti}$ & 3000.0 & $\mathrm{Sr}$ & 120.00 & $\mathrm{Ce}$ & 25.00 & $\mathrm{Hf}$ & 0.40 \\
\hline $\mathrm{FeO}$ & 5.70 & $\mathrm{Mn}$ & 800.00 & $\mathrm{Nb}$ & 5.70 & Sm & 3.90 & $\mathrm{TI}$ & 0.40 \\
\hline $\mathrm{MnO}$ & 0.15 & $\mathrm{Cr}$ & 210.00 & $\mathrm{Zr}$ & 16.00 & $\mathrm{Nd}$ & 18.00 & W & 1.50 \\
\hline $\mathrm{MgO}$ & 3.51 & Co & 22.00 & Mo & 1.20 & $\mathrm{Eu}$ & 1.00 & $\mathrm{~Pb}$ & 9.00 \\
\hline $\mathrm{CaO}$ & 2.86 & $\mathrm{Ni}$ & 40.00 & $\mathrm{Ag}$ & 0.16 & $\mathrm{Gd}$ & 4.00 & $\mathrm{Bi}$ & 0.17 \\
\hline $\mathrm{NaO}$ & 1.72 & $\mathrm{Cu}$ & 40.00 & $\mathrm{Cd}$ & 0.07 & $\mathrm{~Tb}$ & 0.60 & Th & 5.00 \\
\hline $\mathrm{K}_{2} \mathrm{O}$ & 2.53 & $\mathrm{Zn}$ & 80.00 & Sn & 1.30 & Dy & 3.70 & $U$ & 2.10 \\
\hline \multicolumn{10}{|l|}{ Loss on } \\
\hline ignition & 5.30 & $\mathrm{Ga}$ & 20.00 & $\mathrm{Sb}$ & 0.15 & $\mathrm{Ho}$ & 0.70 & - & - \\
\hline Total & 99.75 & $\mathrm{Ge}$ & 1.30 & $\mathrm{Te}$ & 0.02 & $\mathrm{Er}$ & 2.20 & - & - \\
\hline
\end{tabular}
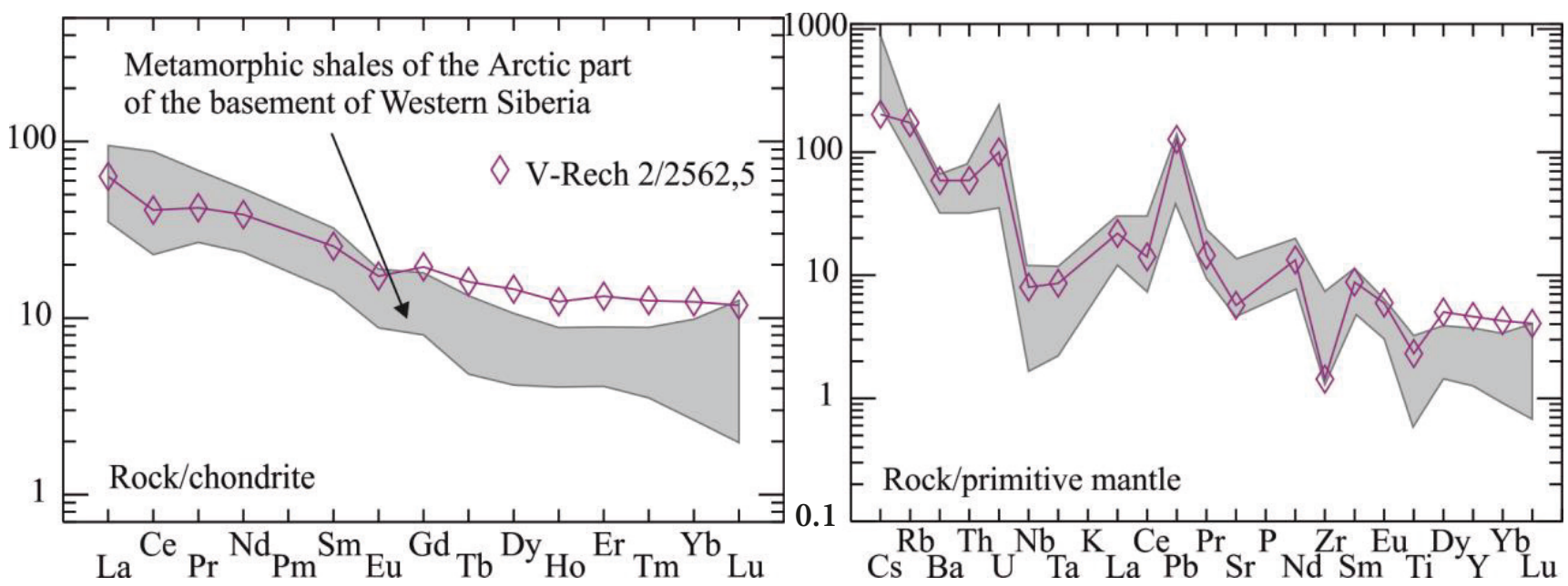

Figure 6. Distribution of rare earth elements in garnet-quartz-chlorite-muscovite schists normalized to chondrite. Well Verkhnerechenskaya 2, depth is $2562.5 \mathrm{~m}$

Рисунок 6. Распределение редкоземельных элементов в гранат-кварц-хлорит-мусковитовых сланцах, нормированных на хондрит. Скв. Верхнереченская 2, глубина 2562,5 м

Figure 7. Distribution of rare, trace and rare-earth elements in garnet-quartz-chlorite-muscovite schists normalized to the primitive mantle. Well Verkhnerechenskaya 2, depth is $2562.5 \mathrm{~m}$

Рисунок 7. Распределение редких, рассеянных и редкоземельных элементов в гранат-кварц-хлорит-мусковитовых сланцах, нормированных на примитивную мантию. Скв. Верхнереченская 2, глубина 2562,5 м

The chemical composition of garnet-quartz-chlorite-muscovite schist is shown in table 4 . $\mathrm{SiO}_{2}$ content 57.36 wt. $\% ; \mathrm{Al}_{2} \mathrm{O}_{3} 16.90$ wt.\%. The metamorphic schists have high concentrations (in ppm): $\mathrm{Ti}(3000), \mathrm{V}(120)$, $\mathrm{Cr}$ (210), Mn (800), Rb (110), Sr (120), and Ba (410). The content of rare earth elements in metamorphic schists is quite high - $80.82 \mathrm{ppm}$ (table 4). The distribution trend of rare earth elements normalized to chondrite [16] is characterized by the predominance of light lanthanides over heavy ones with a slight negative Ce and Er anomaly (fig. 6). The spider plot of the distribution of rare, trace and rare earth elements normalized to the primitive manthe [16] in schits is characterized by positive anomalies in $\mathrm{U}, \mathrm{Pb}$ and negative anomalies in $\mathrm{Nb}, \mathrm{Ta}, \mathrm{Zr}$, and Ti (fig. 7).

\section{Discussion of results}

The mineralogy of garnet-quartz-chlorite-muscovite schists from the Verkhnerechenskaya well no. 2 differs from the previously studied metapelites from the preJurassic basement of the southern part of the Yamal Peninsula (Zapadno-Yarotinskaya well no. 300 [5]) and schists from the basement of the Tazovsky Peninsula (Lenzitskaya well no. 77 [15]) by the presence of almandine, titanite and xenotime-(Y). The high concentration of titanium in the rocks is due to the presence of rutile, the main accessory mineral of schists. This is also related to the presence of significant amounts of vanadium, which is the main impurity element in rutile. The increased content of rubidium is directly related to 
the main rock-forming mineral, mica, because rubidium has a geochemical affinity for potassium. The concentration of manganese is associated with micas and, in some places, chlorite, which enters the position of iron isomorphically. The high content of strontium in some schists is due to the presence of abundant carbonate mineralization, since it is known that strontium likes to enter the position of calcium in carbonates. The same applies to barium, which is an impurity element in carbonates and feldspars, although in some cases it forms its own minerals (barite) in schists. The significant presence of chromium in schists is most likely associated with accessory impregnation of magnetite.

In general, the distribution of rare, scattered and REE in the studied rocks is characteristic of metamorphic schists from the basement of the Ural part of the West Siberian megabasin, which form the framing of monzodiorite-granite massifs of the Shaimsko-Kuznetsovsky meganticlinorium (Tolumskaya, Maloteterevskaya, Okunevskaya areas within the Shaimsky oil and gas bearing region) in Western Siberia [2]. It is possible that metamorphic schists from the basement of the Arctic part of the West Siberian plate and the Ural part of Western Siberia were formed as a result of greenschist metamorphism of sedimentary rocks similar in composition.

Metapelites are one of the most widespread metamorphic rocks of the basement of the Ural part of the West Siberian plate, including the large Shaimsko-Kuznetsovsky meganticlinorium $[2,17]$. Compositionally close to the studied rocks, garnet-quartz-muscovite and garnetbiotite quartz schists are found in the basement of the Vostochno-Urayskaya area of the Shaimsky region of Western Siberia; the authors attribute them to products of the muscovite-horny facies of contact metamorphism caused by the proximity to the gabbro intrusion [11].
Since we are not able to see the complete section of the basement rock strata along the well, we can only assume that the studied schists may be the product of contact metamorphism of the inner zone, which is more distant from contact with the heat source. In our case, most likely, garnet-quartz-chlorite-muscovite schists were formed due to the heating of sedimentary rocks by a closely located granite intrusion. At the same time, it is impossible to exclude the formation of studied schists as a result of regional greenschist metamorphism. Later, the rocks underwent changes in the process of propylitization with the formation of carbonate and pyrite.

\section{Conclusions}

Thus, we have described in detail the mineralogy and obtained the trace element composition of garnetquartz-chlorite-muscovite schists from the pre-Jurassic basement of the southern part of the Yamal Peninsula (well no. Verkhnerechenskaya 2, depth is $2562.5 \mathrm{~m}$. The mineral composition of the rocks is as follows: almandine, muscovite, quartz, chamosite, calcite, albite, rutile, titanite, fluorapatite, zircon, xenotime-(Y) and pyrite. The progressive zonality in the almandine is determined, which is confirmed by the calculated data of metapelite formation temperature, progressive metamorphism. Distribution of rare, scattered and REE in the studied rocks is characteristic of metamorphic schists from the foundation of the Urals part of the West Siberian megabasin, which compel the framing of monzodiorite-granite massifs of Shaimsko-Kuznetsovsky meganticlinorium of Western Siberia. Probably, the metapelites studied are the result of warming up the thickness of sedimentary rocks with granite intrusion located in the vicinity of Verkhnerechenskaya area. Later, the rocks underwent propylitization with the formation of secondary carbonate and pyrite.

The authors are grateful to I. A. Gottman and other employees of the laboratory of Zavaritsky Institute of Geology and Geochemistry of the Ural Branch of the Russian Academy of Sciences, for their help in analytical work.

The work was supported by RFBR grant 18-05-70016.

\section{REFERENCES}

1. Ivanov K. S., Fedorov Yu. N., Ponomarev V. S., Koroteev V. A., Erokhin Yu. V. 2012, Nature and age of metamorphic rocks from the basement of the West Siberian megabasin (according to U-Pb isotopic dates). Doklady Earth Sciences, vol. 443, part 1, pp. 321-325. https://doi.org/10.1134/ S1028334X12030129

2. Ivanov K. S., Fedorov Yu. N., Erokhin Yu. V., Ponomarev V. S. 2016, Geological structure of the basement of the Priuralskaya part of the West Siberian oil and gas megabasin. Ekaterinburg, 302 p. (In Russ.)

3. Tugareva A. V., Moroz M. L., Chernova G. A., Belova E. V. 2018, The granitoid magmatism in the territory of Frolovskaya megadepression of Western Siberia. Izvestiya vysshikh uchebnykh zavedeniy. Neft' i gaz [Oil and Gas Studies], no. 6, pp. 33-40. (In Russ.) https://doi.org/10.31660/0445-0108-2018-6-33-40

4. Erokhin Yu. V., Ivanov K. S., Koroteev V. A., Khiller V. V. 2017, Mineralogy of inclusions and age of zircon from granite basement of the Verkhnerechensk area (Yamal Peninsula). Litosfera [Lithosphere], vol. 17, no. 6, pp. 81-90. (In Russ.) . https://doi.org/10.24930/1681-9004-20176-081-090

5. Erokhin Yu. V., Khiller V. V., Ivanov K. S., Rylkov S. A., Bochkarev V. S. 2014, Mineralogy of metamorphic schists from the pre-Jurassic base the Yamal Peninsula southern part. Litosfera [Lithosphere], no. 5, pp. 136-140. (In Russ.)

6. Khiller V. V. 2020, Chemical composition and age of monazite-(Ce) in granitoids of the crystalline basis from the South Yamal. Izvestiya Ural'skogo gosudarstvennogo gornogo universiteta [News of the Ural State Mining University], issue 4 (60), pp. 28-34. https://doi.org/10.21440/ 2307-2091-2020-4-28-34

7. Rudkevich M. Ya. 1969, Tectonics of the West Siberian Plate and its regionalization in terms of oil and gas potential. Trudy ZapSibNIGNI [Proceedings of the West Siberian Research Institute geology and geophysics]. Moscow, vol. 14, 280 p. (In Russ.)

8. Bochkarev V. S. 2018, Distribution of Precambrian metamorphites, carbonate platforms and Paleozoic covers of the West Siberian geosyneclise (methodological and geophysical aspect). Geologiya nefti i gaza [Geology of oil and gas], no. 3, pp. 49-58. (In Russ.) https://doi.org/10.31087/0016-7894-2018-3-49-58 
9. Ivanov K. S., Koroteev V. A., Erokhin Yu. V., Ponomarev V. S., Travin A. V. 2020, First data on the age at metamorphic schists from the Taz Peninsula (Arctic, Western Siberia). Doklady Earth Science, vol. 491, part 1, pp. 135-138. https://doi.org/10.1134/S1028334X20030071

10. Rieder M., Cavazzini G., D’yakonov Y. S., Frank-Kamenetskii V. A., Gottardi G., Guggenheim S., Koval' P. V., Müller G., Neiva A. M. R., Radoslovich E. W., Robert J.-L., Sassi F. P., Takeda H., Weiss Z., Wones D. R. 1998, Nomenclature of the micas. Canadian Mineralogist, vol. 36, pp. 905-912.

11. Lepezin G. G., Korolyuk V. N. 1985, Types of zonality in garnets. Geologiya i Geofizika [Geology and Geophysics], no. 6, pp. 71-79. (In Russ.) 12. Erokhin Yu. V., Ivanov K. S., Fedorov Yu. N. 2008, Contact metamorphism in the pre-Jurassic basement of the Shaimsky region of the West Siberian megabasin. State, trends and problems of the development of oil and gas potential of Western Siberia. Tyumen, pp. 174-182. (In Russ.) 13. Hanes A., Forest R. C. 1988, Empirical garnet-muscovite geothermometry in low-grade metapelites, Selwyn Range (Canadian Rockies). Journal of Metamorphic Geology, vol. 6, no. 6, pp. 297-309.

14. Cathelineau M., Neiva D. 1985, A chlorite solid solution geothermometer the Los Asufres (Mexico) geothermal system. Contributions to Mineralogy and Petrology, vol. 91, pp. 235-244.

15. Ponomarev V. S., Ivanov K. S., Khiller V. V. 2019, Mineralogy of schists from the basement of the southwestern part of the Tazovsky peninsula of the West Siberian megabasin (Lenzitskaya oil exploration area, YNAD). Izvestiya Ural'skogo gosudarstvennogo gornogo universiteta [News of the Ural State Mining University], no. 2 (54), pp. 20-27. https://doi.org/10.21440/2307-2091-2019-2-20-27

16. Sun S. S., McDonough W. F. 1989, Chemical and isotopic systematics of oceanic basalts: implications for mantle composition and processes. In: Magmatism in Ocean Basins. London: Geol. Soc. Spec. Publ., pp. 313-345. https://doi.org/10.1144/GSL.SP.1989.042.01.19

17. Ivanov K. S., Koroteev V. A., Ponomarev V. S., Erokhin Yu. V. 2018, Precambrian complexes of the West Siberian plate: problem and solution. Doklady Earth Sciences, vol. 482, part 1, pp. 1152-1156. 


\title{
Особенности состава метапелитов из фундамента Арктической части Запацно-Сибирского мегабассейна (Верхнереченская разведочная плошаць, полуостров Ямаи)
}

\author{
Владимир Сергеевич ПОНОМАРЕВ* \\ Кирилл Святославич ИВАНОВ** \\ Юрий Викторович ЕРОХИН*** \\ Надежда Николаевна ФАРРАХОВА****
}

Институт геологии и геохимии им. А. Н. Заварицкого УрО РАН, Екатеринбург, Россия

Аннотация

Aктуальность paботьљ. Комплексные исследования геологии Арктической части Западной Сибири весьма важны для поиска нефти и газа на этой огромной, но недостаточно изученной территории. В настоящее время, к сожалению, мы мало что знаем о геологическом строении Арктики в области Западной Сибири, где в основном исследуется осадочный чехол, мощность которого около 3-4 км, и лишь немногие скважины пробурены до фундамента. Поэтому всестороннее изучение образцов керна из этой малоизученной территории представляется крайне актуальным.

Целью работы является подробное описание минералогии и петролого-геохимических особенностей гранат-кварц-хлорит-мусковитовых сланцев из скважины Верхнереченская № 2 из фундамента Арктической части Западно-Сибирского мегабассейна.

Область применения работы. Настоящая работа может быть полезна при построении геологических карт доюрского фундамента полуострова Ямал.

Peзультаты paботы и выводы. Детально изучена минералогия и получен микроэлементный состав гранат-кварц-хлорит-мусковитовых сланцев. Минеральный состав пород следующий: альмандин, мусковит, кварц, шамозит, кальцит, альбит, рутил, титанит, фторапатит, циркон, ксенотим-(Y) и пирит. Установлена прогрессивная зональность в альмандине, которая подтверждается расчетными данными температуры образования метапелитов, прогрессивным метаморфизмом. Распределение редких, рассеянных и РЗЭ в исследуемых породах характерно для метаморфических сланцев из фундамента Приуральской части Западно-Сибирского мегабассейна, слагающих обрамление монцодиорит-гранитных массивов ШаимскоКузнецовского мегантиклинорияЗападной Сибири. Вероятно, исследуемыеметапелиты являются результатом прогрева толщи осадочных горных пород гранитной интрузией, расположенной в непосредственной близости на территории Верхнереченской площади. Позже породы подверглись пропилитизации с образованием вторичного карбоната и пирита.

Ключевые слова: минералогия, метаморфические сланцы, метапелиты, фундамент, полуостров Ямал, Западная Сибирь.

\section{ЛИТЕРАТУРА}

1. Ivanov K. S., Fedorov Yu. N., Ponomarev V. S., Koroteev V. A., Erokhin Yu. V. Nature and age of metamorphic rocks from the basement of the West Siberian megabasin (according to U-Pb isotopic dates) // Doklady Earth Sciences. 2012. Vol. 443. Part 1. P. 321-325. https://doi. org/10.1134/S1028334X12030129

2. Иванов К. С., Федоров Ю. Н., Ерохин Ю. В., Пономарев В. С. Геологическое строение фундамента Приуральской части ЗападноСибирского нефтегазоносного мегабассейна. Екатеринбург: Ин-т геологии и геохимии УрО РАН, 2016. 302 с.

3. Тугарева А. В., Мороз М. Л., Чернова Г. А., Белова Е. В. Гранитоидный магматизм в пределах Фроловской мегавпадины Западной Сибири // Известия вузов. Нефть и газ. 2018. № 6. С. 33-40. https://doi.org/10.31660/0445-0108-2018-6-33-40

4. Ерохин Ю. В., Иванов К. С., Коротеев В. А., Хиллер В. В. Минералогия включений и возраст циркона из гранитов фундамента Верхнереченской площади (полуостров Ямал) // Литосфера. 2017. Т. 17. № 6. С. 81-90. https://doi.org/10.24930/1681-9004-2017-6-081-090 5. Ерохин Ю. В., Хиллер В. В., Иванов К. С., Рыльков С. А., Бочкарев В. С. Минералогия метаморфических сланцев из доюрского основания южной части полуострова Ямал // Литосфера. 2014. № 5. С. 136-140.

6. Khiller V. V. Chemical composition and age of monazite-(Ce) in granitoids of the crystalline basement from the South Үатаl // Известия УГГУ. 2020. Вып. 4 (60). C. 28-34. https://doi.org/10.21440/2307-2091-2020-4-28-34

$\triangle \mathrm{p} 123 \mathrm{v} @ y a n d e x . r u$

https://orcid.org/0000-0002-1651-1281

"ivanovks@igg.uran.ru

(iD) https://orcid.org/0000-0002-8292-4658

"'erokhin-yu@yandex.ru

https://orcid.org/0000-0002-0577-5898

atlantida21@mail.ru

https://orcid.org/0000-0002-3067-4044

В. С. Пономарев и др. Особенности состава метапелитов из фундамента Арктической части Западно-Сибирского мегабассейна 37 (Верхнереченская разведочная площадь, полуостров Ямал)//Известия УГГУ. 2021. Вып. 2 (62). С. 29-38. DOI 10.21440/2307-2091-2021-2-29-38 
7. Рудкевич М. Я. Тектоника Западно-Сибирской плиты и ее районирование по перспективам нефтегазоносности // Труды ЗапСибНИГНИ. М.: Недра, 1969. Вып. 14. 280 с.

8. Бочкарев В. С. Распространение докембрийских метаморфитов, карбонатных платформ и палеозойских чехлов Западно-Сибирской геосинеклизы (методико-геофизический аспект) // Геология нефти и газа. 2018. № 3. C. 49-58. https://doi.org/10.31087/0016-7894-2018-349-58

9. Ivanov K. S., Koroteev V. A., Erokhin Yu. V., Ponomarev V. S., Travin A. V. First data on the age at metamorphic schists from the Taz Peninsula (Arctic, Western Siberia) // Doklady Earth Sciences. 2020. Vol. 491. Part 1. P. 135-138. https://doi.org/10.1134/S1028334X20030071

10. Rieder M., Cavazzini G., D’yakonov Y. S., Frank-Kamenetskii V. A., Gottardi G., Guggenheim S., Koval' P. V., Müller G., Neiva A. M. R., Radoslovich E. W., Robert J.-L., Sassi F. P., Takeda H., Weiss Z., Wones D. R. Nomenclature of the micas // Canadian Mineralogist. 1998. Vol. 36. P. 905-912.

11. Лепезин Г. Г., Королюк В. Н. Типы зональности в гранатах // Геология и геофизика. 1985. № 6. С. 71-79.

12. Ерохин Ю. В., Иванов К. С., Федоров Ю. Н. Контактовый метаморфизм в доюрском основании Шаимского района Западно-Сибирского мегабассейна // Состояние, тенденции и проблемы развития нефтегазового потенциала Западной Сибири. Тюмень: ЗапСибНИИГГ, 2008. C. 174-182.

13. Hanes A., Forest R.C. Empirical garnet-muscovite geothermometry in low-grade metapelites, Selwyn Range (Canadian Rockies) // Journal of Metamorphic Geology. 1988. Vol. 6. No .6. P. 297-309.

14. Cathelineau M., Neiva D. A chlorite solid solution geothermometer the Los Asufres (Mexico) geothermal system // Contributions to Mineralogy and Petrology. 1985. Vol. 91. P. 235-244.

15. Ponomarev V. S., Ivanov K. S., Khiller V. V. Mineralogy of schists from the basement of the southwestern part of the Tazovsky Peninsula of the West Siberian megabasin (Lenzitskaya oil exploration area, YNAD) // Известия УГГУ. 2019. № 2 (54). С. 20-27. https://doi.org/10.21440/23072091-2019-2-20-27

16. Sun S. S., McDonough W. F. Chemical and isotopic systematics of oceanic basalts: implications for mantle composition and processes // Magmatism in Ocean Basins. London: Geol. Soc. Spec. Publ., 1989. P. 313-345. https://doi.org/10.1144/GSL.SP.1989.042.01.19

17. Ivanov K. S., Koroteev V. A., Ponomarev V. S., Erokhin Yu. V. Precambrian complexes of the West Siberian plate: problem and solution // Doklady Earth Sciences. 2018. Vol. 482. Part 1. P. 1152-1156. https://doi.org/10.1134/S1028334X18090234

Статья поступила в редакцию 31 марта 2021 года 